\title{
Relationship Between School Leadership Style and Teachers' Motivation With Teachers Discipline
}

\author{
Ayu Wulandari \\ \{ayuwulandari@stkipkusumanegara.ac.id\} \\ STKIP Kusumanegara, Indonesia
}

\begin{abstract}
The background of this research is based on the teacher's lack of work discipline. There are still teachers who are late for class. In addition there are teachers who are late in collecting lesson plans. The research was conducted at VI Elementary School Elementary School, Palmerah, West Jakarta, with a survey method. The study population amounted to 133 people, while the sample amounted to 100 people, the data were analyzed using correlation and regression techniques. Based on the results of research to improve teacher work discipline can be done with a leadership style that is in accordance with situational motivation and work motivation of the teacher itself.
\end{abstract}

Keywords: Relationship, Leadership Style, Motivation, Discipline, Teacher.

\section{Introduction}

Principal leadership is said to be successful, if it can empower all school resources to achieve goals in accordance with the situation and condition of the school they lead. The principal is required to have professional abilities, namely: personality, basic skills, experience, training and professional knowledge, as well as administrative and supervisory competencies.

In addition to leadership, motivation is also a determinant of educational success. Teachers who have motivation will tend to do their jobs better. Teachers who have motivation are more enthusiastic at work. The students' success in learning is also determined by the teacher's motivation in teaching.

The teacher's work discipline is the belief of a teacher regarding the work carried out which is accompanied by the existence of certain feelings, and provides a basis for the teacher to make a response or behave in a certain way according to his choice. Teacher's work discipline towards work influences the teacher's actions in carrying out his work activities. If a teacher has good discipline on his job, then surely the teacher will carry out his function and position as teaching staff and educators in the school with a full sense of responsibility. Likewise, on the contrary, a teacher who does not have a good work discipline towards his job, must only carry out his function and his position is limited to mere routines. Discipline is an act of obeying and respecting the applicable rules.[1]

This research is to find out the relevance of teacher work discipline with their leadership style and work motivation. Teacher work discipline is an initial component of education that can be used as a source of improvement in improving and improving the quality of education. The ultimate goal is to improve the quality of education in general. 


\section{Theoretical Framework}

\subsection{Discipline}

According to Davis Werther theory, discipline is the management that maintains the formation of one's behavior so that it can be in accordance with predetermined rules standards.[2] This is in line with Leslie W.'s view Rue and Lioyd L Byars, they pointed out that discipline is a condition in an organization where employees must know what is expected by the organization regarding organizational rules, norms and policies and the consequences of violations.[3] The idea is strengthened by Latainer which defines discipline as a force that develops within the employee's body and causes employees to adjust themselves voluntarily to decisions, regulations, and high values of work and behavior, in a narrow sense it is usually associated with punishment.[3]

According to Kassanggie, discipline is divided into two categories, namely self-discipline and institutional discipline.[4] Both have distinctive characteristics, but there are also similarities, teacher self-discipline is a personal discipline that is reflected in the personalities of each teacher, while institutional discipline is the implementation of the discipline of the teachers' work unit based on institutional policy.

According to Robbins Coulter, the types of work discipline problems that often occur include: attendance, workplace behavior, dishonesty and outside employment.[5] The types of problems in discipline can be seen from the visualization of the following table:

Table 1.Types of Discipline Problems

\begin{tabular}{cll}
\hline No. & Types of Discipline Problems & Example \\
\hline 1 & Attendance & $\begin{array}{l}\text { Absenteeism, late for work, abuse of } \\
\text { leave entitlements }\end{array}$ \\
2 & Workplace Behavior & $\begin{array}{l}\text { Ignorance, failure to use safety } \\
\text { devices, abuse of alcohol or drugs }\end{array}$ \\
3 & Dishonesty & $\begin{array}{l}\text { Lying on superiors, stealing, } \\
\text { falsifying information on cover } \\
\text { letters } \\
\end{array}$ \\
4 & Outside Employment & $\begin{array}{l}\text { Working for foreign companies, } \\
\text { carrying out illegal strike activities, } \\
\text { and committing crimes }\end{array}$ \\
\hline
\end{tabular}

Regarding this undisciplined behavior, as stated by Gibson, some behaviors of undisciplined employees can be punished, namely: 1) absenteeism, 2) tardiness, 3) leaving the workplace, 4) stealing, 5) sleeping while working, 6) fighting, 7) threatening superiors, 8) repeating bad performance, 9) committing defiance of boss orders, 10) slowing down work, 11) refusing overtime, 12) damaging office equipment.[6]

According to Davis Newstroom there are 5 (five) types of punishment taken when an offense occurs: 1) verbal reprimand by the leader, 2) written reprimand with notes in the archive, 3) suspension from work for one to three days, 4) suspension for one week or longer, 5) dismissal with acceptable reasons.[7]

From the opinions stated above, it is clear that the discipline has the main characteristic in order, obedience and compliance to achieve organizational goals. Discipline also keeps solving the problems that may arise in the organization that are caused by lack of attention, 
incompetence, willingness, laziness and tardiness committed by employees, in order to keep the initial goals of the organization from deviating.

\subsection{Principal Leadership Style}

In simple terms, a principal can be defined as a functional teacher who is given an additional task to lead a school where there is a teaching and learning process, or a place where interaction occurs between the teacher who gives lessons and students who receive the lesson.

Henry Pratt Fairchid stated that leader in a broad sense is someone who lead, by initiating social behavior by regulating, directing, organizing or controlling the efforts of others, or through prestige, power or position.[8] In a limited sense, a leader is a guide who leads with the help of his persuasive quality, and acceptance voluntarily by his followers. This opinion is strengthened by the opinion of the John Gage Alle stating "the leader is a guide, director, organizer, commander".[9] Reeves argue that leadership is the process of influencing the activities of individuals or groups in efforts toward the goal achievement given situation.[10] Leadership is a way to become a good facilitator, because leaders will free the whole team and their individual members to become effective and innovative.[11]

According to Gisela Hagemann, leadership style reflects staff motivation and requires ethical values, satisfaction / sensitivity, openness, attentiveness, and morale.[12] As it is strengthened by the opinions of Hoy and Miskel, the style that can be applied at school is taskoriented and people-oriented.[12] Task-oriented leadership style is a style that is more concerned with the structure of tasks, preparation of work plans, determination of organizational patterns, work methods and procedures for achieving goals. Whereas, the people-oriented leadership style is more concerned with health, trust, appreciation, and warmth between leaders and members.

In line with the opinions that have been stated above, Hadari Nawawi suggested that in the realization of leadership activities, the leadership style with each pattern can be identified. This leadership style turns out to be the basis for classifying the type of leadership that has three basic patterns in leadership style, namely (1) leadership style that emphasizes the implementation of tasks effectively and efficiently, so that they can realize their goals optimally in carrying out tasks without the intervention of others 2) leadership style that emphasizes the implementation of cooperative relationships, leaders who pay great attention and have a strong desire for each person to be able to cooperate in carrying out their duties (3)leadership style that emphasizes results that can be achieved in order to realize group / organizational goals, so leaders have a strong desire for each member to get an achievement.[13]The results of Nthakyo's research suggested that the principal's leadership style is related to student discipline.[14]

\subsection{Motivation}

Fillmore H. Stanford stated that "Motivation as an energizing condition of organism serves to direct that organism toward the goal of a certain class".[15] Another view stated by Merle J. Moskowits that "Motivation is usually refined the initiation and direction of behavior, and the study of motivation is in effect the study of course of behavior".[16] Furthermore, Edwin B Flippo said that "Direction or motivation is essence; it is the skill in aligning employee and organization interest so that the result behavior in the achement of employee wants simultaneously with attainment or organizational objectives"[16]. 
According to the American Encyclopedia "Motivation: That predisposition (itself the subject of much controversy) within the individual which arouses sustain and direct his behavior.[16] Motivation involves such factors as biological and emotional needs that are inferred from observation behavior). From the thoughts that have been stated above, motivation is the enthusiasm or encouragement to fulfill the needs that will encourage one's work for their survival. Suyanto's research (2018) suggests that increasing motivation can be done by increasing one's discipline.[17]

\section{Method}

The design of this research used the survey method. The populations in this research were teachers of State Elementary Schools in the District VI, Palmerah District, West Jakarta. The total population is 133 teachers. Sampling is done by using Slovin formula. The numbers of samples in this research were 100 teachers. The sampling technique in the research was proportional random sampling. Data analysis was carried out by using regression techniques. Test requirements included normality test, linearity test and homogeneity test.The hypothesis testing formula is done in five stages, namely the linear regression equation test, regression significance test, linearity test, correlation test, and correlation significance.[18] (https://osf.io/yucgs/).

Based on the theory description and the conceptual framework, the research hypothesis can be formulated as follows:

a. There is a positive relationship between the principals' leadership style and the teachers' work discipline.

b. There is a positive relationship between teachers' motivation and work discipline

c. There is a positive relationship between the principals' leadership style and the motivation of the teachers' work together with the work discipline.

\section{Result}

\subsection{Data Description}

\subsubsection{Teachers' Work Discipline Variables (Y)}

The results of the research showed that the respondent's answer score ranged from 71 to 94 ; the range of scores was obtained from the number of items contained in the research instrument consist of 21 statement items. From the calculation of analysis with the help of SPSS Version 22, the following data were obtained: maximum value $=94$, minimum value $=71$, average $=83.27$, standard deviation $=5.077$, mode $=85$ and median $=84$.

\subsubsection{Leadership Style (X1)}

Theresults of the research showed that the respondents' answer score ranged from 80 to 117 , the range of scores was obtained from the number of items contained in the research instrument comprising 26 statement items. From the calculation of the analysis with the help of SPSS Version 22, the following data were obtained: maximum value = 
117, minimum value $=80$, average $=97.96$, standard deviation $=8.806$, mode $=99$ and median $=97$.

\subsubsection{Teacher Work Motivation Variable (X2)}

Theresults of the research showed that the respondents' answer scores ranged from 65 to 86 , the range of scores was obtained from the number of items contained in the research instrument which consist of 20 items. From the calculation of the analysis, with the help of SPSS Version 22, the following data were obtained: maximum value $=86$, minimum value $=65$, average $=75.72$, standard deviation $=4.748$, mode $=78$ and median $=76$.

\subsection{Test Analysis Requirements}

\subsubsection{The Results Of The Research and Discussion}

There is a positive relationship between the principal's leadership style and the teacher's work discipline.

Based on the results of calculations, it is known that there is a positive relationship between the principal's leadership styles towards the teacher's work discipline. The results of the regression significance test based on the ANOVA table were F count (4250.32) $>\mathrm{F}$ table (6.93) at $\alpha=0.05$. This shows that accepting $\mathrm{H} 1$ or accepting the working hypothesis means there is a significant relationship between the principal's leadership styles towards the teacher's work discipline.

These results indicate that the principal's leadership style has a positive relationship with the teacher's work discipline. To make teachers behave in a discipline, the principal should apply the style that the teacher likes. Principals that are oriented towards creating good relationships with teachers will be able to increase teacher awareness to display behaviors that are in accordance with the school rules.

There is a positive relationship between teacher motivation and teachers' work discipline.

Based on the results of calculations, it is known that there is a positive relationship between teacher work motivation towards teacher work discipline, the results of the regression significance test based on the ANOVA table were F count (4598.23)> F table (6.93) at $\alpha=0.05$. This shows that accepting H1 or accepting the working hypothesis means that there is a significant relationship between the motivations of the teacher's work towards the teacher's work discipline.

These results indicate that teacher work motivation relates to their work discipline. Teachers who have motivation in working will be more disciplined in carrying out their duties. The higher the teacher's motivation, the better the discipline they do. The acquisition of enough salary and encouragement to do the best can trigger the teacher to be more disciplined at work.

There is a positive relationship between the principal's leadership style and the motivation of the teacher's work together with the teacher's work discipline.

Based on the results of calculations, it is known that there is a relationship between the principal's leadership style and teacher's work motivation together with the teacher's work discipline, the results of the test of regression significance based on the ANOVA 
table were F count $(2613,472)>\mathrm{F}$ table $(6,93)$ on $\alpha=0.05$. This shows that accepting H1 or accepting the working hypothesis means that there is a significant relationship between the principal's leadership style and the motivation of the teacher's work with the teacher's work discipline.

These results indicate that the teacher's work motivation and the principal's leadership style are cooperatively related to the teacher's work discipline. The principal should apply the leadership style favored by the teachers. In addition, the motivation of the teacher should also be well-maintained. Intrinsic and extrinsic motivation must always be improved so that the teachers' work discipline becomes better.

\section{Conclusion}

Based on the results of the research it can be concluded that leadership style has a positive relationship with teachers' work-discipline. Furthermore, the teacher's work motivation also has a positive relationship with the teachers' work discipline. Jointly, the leadership style and work motivation of the teacher relates to the teachers' work discipline.

\section{References}

[1] Z. M. Elqadri, P. Priyono, R. P. Suci, and T. Chandra, "Effect of Leadership Style, Motivation, and Giving Incentives on the Performance of Employees-PT. Kurnia Wijaya Various Industries," International Education Studies, vol. 8, p. 183, 2015.

[2] W. B. Werther and K. Davis, Human resources and personnel management: Harper San Francisco, 1989.

[3] L. W. Rue and L. L. Byars, Supervision Key Link to Producvity: Fifty Ediontion United Stated of America, 1996.

[4] R. F. K. . Organization Behavioral: Houhton Miffins, 2000.

[5] S. P.Robbins and M. J. Coulter, Management. New Jersey: Prentice Hall.Inc., 1999.

[6] J. L. G. . Organization. Jakarta: Erlangga, 1985.

[7] K. D. J. W.Newstrom, Perilaku Organisasi. Jakarta: Erlangga, 1996.

[8] H. P. Fairchild, Dictionary of Sociology [and Related Sciences]: Littlefield, Adams, 1965.

[9] J. G. Allee, "Webster's New Standar Dictionary," ed: New York: Mc Loughlin Brothers Inc, 1969.

[10] D. B. Reeves and S. Ventura, "i Leadership," AGENDA, 2012.

[11] J. Adair, Develop Your Leadership Skills. London: Kogan Pages, 2007.

[12] G. Hagernann, Motivation Manual. England: Gower Publishing, 1993,.

[13] H. Nawawi, Kepemimpinan yang Efektif. Yogyakarta: Gadjah Mada University press, 2000.

[14] G. N. Katolo, "Principals' leadership practices and their influence on students' discipline in public secondary schools in Makindu sub county, Kenya," 2016.

[15] M. P. Anwar, Manajemen Sumber Daya Manusia Perusahaan. Bandung: RemajaRosdakarya, 2011.

[16] M. S.P.Hasibuan, Manajemen Sumber Daya Manusia. Jakarta BumiAksara, 2006.

[17] S. Suyanto, "Competence and Discipline on Work Motivation and the Implication on Working Performance," European Research Studies Journal, vol. 21, pp. 570-587, 2018.

[18] A. Wulandari, "Relationship Between School Leadership Style and Teachers' motivation with teachers' discipline," ed, 2019, January 2. 